\title{
2. Megismeréstervezetek
}

\section{AndrÁs ZsELYKe* \\ A KÉT VILÁGHÁBORÚ KÖZTI ERDÉLYI MÚZEUM SZERZÖINEK TUDOMÁNYFELFOGÁSA}

\author{
Kulcsszavak: tudománykoncepció, tudományelmélet, tudománytörténet, irodalomelmélet, \\ filozófiatörténet.
}

Az idén nyáron Sepsiszentgyörgyi Tudományos Napokat szervezett Egyed Emese tanárnő, ahol egy kutatócsoport tagjaként a készülő doktori dolgozatomhoz gyűjtöttem háttéradatokat a Teleki Domokos Könyvtárban (a Székely Mikó Kollégium épületében). Arra gondoltam, hogy az említett folyóirat termékenyebb bölcsész szerzőinek egyéb írásait tanulmányozom át, hogy tudományos elképzeléseikről, koncepcióikról valamiféle fogalmat alkothassak, és az Erdélyi Múzeum-beli tevékenykedésük irányvonalait fontosabb munkáik alapján megérthessem. Miután átnéztem az Erdélyi Múzeum érintett lapszámait, némi mérlegelés után a következő tudósokra esett a választásom tanulmányaik tudományelméleti érintettsége, kutatási módszertanuk kirajzoltsága, az e területet érintő fejtegetéseik nyomán (a döntésemet természetesen nagyban befolyásolta az a tény is, hogy abban a speciális dokumentációs könyvtárban csak néhány érintett szerzőtől találtam anyagot): Jancsó Elemér irodalomtörténész, Kristóf György irodalomtörténész, valamint Tavaszy Sándor református teológiai tanár és filozófus.

Jancsó Elemér 1942-ig a kolozsvári Református Kollégium tanáraként dolgozott, és közben az Erdélyi Múzeum munkatársaként is buzgón tevékenykedett. Legfontosabb tanulmánya az említett időszakból az Erdélyi Múzeum történetéhez kapcsolódóan a Döbrentei Gábor élete és munkássága című (Kolozsvár, Minerva,1944). Döbrentei Gábor hozta létre a ma is működő, hosszú előtörténetre visszatekintő Erdélyi Múzeum folyóirat előzményét, az Erdélyi Muzéumot, amely 1814-1818 között jelent meg, összesen tíz lapszámban. Jancsó Elemér tanulmányában arra összpontosít, hogy tudatosítsa az olvasókban, hogy tudományos kiadványunk egyedülállóan multidiszciplináris jellege szellemi örökségként a 19. századi közlöny össztudományos felfogásából hagyományozódott át. Döbrentei folyóirata volt a Habsburg Birodalom egyetlen magyar szépirodalmi és tudományos kiadványa a Tudományos Gyüjtemény megindulása előtt. Mivel unikum volt, nyilván minden tudományos eredményt össze kívánt gyüjteni és felmutatni, ezért sajátos egyvelege lett a különböző tudományos kezdeményezéseknek. Összetartotta és munkaközösségbe tömörítette Erdély valamennyi tudó-

ANDRÁs Zselyke doktorandusz, az EME Kutatóintézetének nyelvésze. 
sát és íróját, mélyreható érdeklődést keltett a nemzeti nyelv és műveltség iránt. A gazdag főúri rétegben felébresztette a nemzeti feladatvállalás gondolatát. A mecénási elköteleződés tradíciója is átöröklődött a későbbi Erdélyi Múzeumba, Erdély 20. századi befolyásos arisztokrata köreiben is becsületbeli ügynek számított kiadványunk anyagi és szellemi támogatása. Jancsó Elemér szavaival: az a szellemi kézfogás, amit az Erdélyi Muzéum négy éve jelentett, annak megszűnése után is tovább élt, tovább hatott. E régi közlöny amiatt is kuriózum tudománytörténeti és irodalomtörténeti szempontból, mert a korszak legtehetségesebb, irodalmi irányzatokat megteremtő írói, költői jelentették meg szerzeményeiket hasábjain: Kazinczy Ferenc, Berzsenyi Dániel, Batsányi János, Kölcsey Ferenc, Szemere Pál, Vitkovics Mihály, Ungvárnémeti Tóth László stb.

Jancsó tanulmányának egyik alfejezete Döbrentei Gábor munkásságának jelentőségét tárgyalja. Arra a következtetésre jut, hogy művelődés- és tudományszervezői tevékenysége a leginkább kiemelkedő. Megalapítja Tudós Társaságát, és egyik legmeghatározóbb irodalomtörténeti lépése, az, ami, gondolom, a jelenlevők előtt sem titok, hogy kiírta azt a bizonyos drámapályázatot, amelynek apropóján megszületett a Bánk bán Katona József tollából. Az is kultúrtörténeti fontosságú, meghökkentő fordulat mai szemmel, hogy az egyik legismertebb és elismertebb korabeli magyar drámánk nem nyerte el a fődíjat. Ezután rengeteg atrocitás éri Döbrenteit a Katona-mű mellőzése folyományaként, bár Gyalui Farkas némi irodalomtörténeti búvárkodás után arra a következtetésre jut, hogy a Bánk bán kézirata valószínúleg nem jutott le Kolozsvárra.

Döbrentei tudományos pályafutásának másik fontos állomása a régi magyar nyelvemlékek összegyüjtésére tett kísérlete, nagyon sok fontos nyelvtörténeti dokumentumra hívta fel a figyelmet. Tudósunk is tehát tipikus 19. századi polihisztor vonásokat villant fel személyiségében, és ez az össztudományos érdeklődés hagy nyomot folyóiratának profilján is, és ezt az értékes elköteleződést kell, hogy fenntartsa a továbbiakban Jancsó szerint a stafétaváltások nyomán is az Erdélyi Múzeum.

Kristóf György irodalomtörténész két világháború közti tudományos munkásságát három jellemző írása alapján vettem górcső alá, ezek a tanulmányok, kötetek az erdélyi tudományművelés, ezenbelül főként az irodalom- és nyelvtudomány berkeibe kalauzolnak el, és érintőlegesen foglalkoznak nagy múltú folyóiratunk, valamint a háttérintézmény, az EME életműködésével, annak problematikusságával is.

Az első nagyobb lélegzetű tanulmány, amelyre kitérnék, a Tudományművelés - kollégiumainkban című, amely egy különlenyomat a Református Szemle 1931-es összevont számaiból.

A címadó cikk gondolatai a tanárok szerepvállalása körül forognak, ami a tudományművelést illeti. Kiemeli a szerző a pedagógusok kiemelten fontos szerepét a tudomány terjesztésében, népszerűsítésében, de sajnálattal azt is megjegyzi, hogy a produktív kutatói szerepkör nem kötelezhető, nem tartozik elsőrendű feladataik közé. Ennek ellenére módját kell találni annak, hogy a tanárok részt vehessenek konferenciákon, tanulmányutakon vagy továbbképző tanfolyamokon.

Megállapítja általánosságban, hogy a kultúrellenes állapottól, az irodalmi s általában a szellemi élet elsekélyesedésétől a tudományos munka megbecsülése, a műveltség tudományon alapuló elemeinek múvelése és ébren tartása óvhat meg. Nagyon fontosnak tartja a tudományos eredmények megismerését, éspedig nem másodkézből, esetleg napilapoknak felhígított közleményeiből, hanem első forrásból, magukból a mưvekből vagy szakfolyóiratokból. A leg- 
inkább értékelendő Kristóf szerint is a kreatív tudományművelés, a saját tudományos kutatás. Ahhoz viszont, hogy ezt szakszerűen végezhessék a tudományos életbe bekapcsolódni kívánók, elkerülhetetlen a kollégiumok könyv-, kézirat- és levéltárainak tudományos bibliográfiai leírása, ismertetése. Ugyanez áll a másnemű gyüjteményekre is.

Tanulmányának harmadik fejezetében (Nyelvművelés - kollégiumainkban) mint vérbeli filológus külön figyelmet fordít a korabeli nyelvhasználati kérdésekre. Nyelvmúveléspárti: szükség van a magyar nyelv életébe való beavatkozásra, mert hanem óhatatlanul bekövetkezik a nyelvromlás, nyelvvesztés. Nehezményezi, hogy az Akadémia nem fordít gondot a magyar nyelv fejlődésére, tisztaságára, a fejlődés állandó ellenőrzésére. Négyesy László volt az, aki elsőként indítványozta a 20. század elején, hogy újra tervszerű legyen a nyelvművelés. Kisebbségi léthelyzetben, Erdélyben ez az igény gyorsan meggyökeresedett értelmiségi körökben, a magyar öntudat megerősödésével egy időben.

Szerzőnk szerint az erdélyi magyarság nyelvhasználatában még külön, sajátos hibák is mutatkoznak: színtelen kiejtés, fakó hangsúlyozás (szerinte a magyar nyelvjárások hanglejtése nem nevezhető szépnek). Ebből következően romlik a helyesírás is. Ma már megmosolyogjuk ezt a túlzott purizmust, de az időben ez természetes volt, harcosak voltak még a nyelvvédők. Elítéli azt is, hogy az erdélyi magyarok szókincsében tömérdek a felesleges idegen szó (mentalitás, prefektúra, kárnet stb.), és úgy véli, a leginkább az iskolai nyelvben tengenek túl (media, trimesztrális, inspector stb.). Elítéli, ha magyar szövegkörnyezetbe beékelődnek román szövegrészletek: pl. az iskolája Értesítőjében olvasta: „Iskolánkat meglátogatta D1. Al. Popescu inspector regional ..."1. Ez a fajta törekvés a nyelv tisztaságára ma is követendő példa kellene, hogy legyen, hiszen az ún. félnyelvűség, kevertnyelvűség ma már nagyon fenyegető jelenség. Ezek azok az esetek, mikor nem alakul ki a kiegyensúlyozott kétnyelvűség, hanem a mérleg átbillen az egyik nyelv rovására.

Szóvá teszi Kristóf György azt is, hogy rengetegszer hibázunk szókötésben, mondatszerkesztés közben (kell menjek, meg kell nézze) - ezek a fajta szerkezetek szerinte vaskos provincializmusok. (Ma már elfogadott regionalizmusok).

A korszak divatos nyelvmúvelő törekvése az idegen közszók és tulajdonnevek magyarítása. Szerinte kívánatos lenne magyarítani a híres emberek nevét: mint pl. Saw Bernát a G. Bernard Shaw helyett. Bizonyos esetekben él a keresztnevek magyaros írásmódja ma is, a nagyon ismert személyiségek előnevét magyarul használjuk, ilyen pl. Luther Márton, Kolumbusz Kristóf stb. Ilyenkor a nevek sorrendjét is a magyar szokás szerint használjuk, de ezt nem lehet kiterjeszteni és általánosítani. Ezek a magyarosan írt nevek számítanak inkább kivételnek.

Egy másik javaslata, amely nem elvetendő, hogy a magyar tankönyveket át kell vizsgálni nyelvhelyességi szempontból, és hogy kötelezővé kellene tenni a diákság számára a helyesírási szabályzat rendszeres tanulmányozását. A jelenkor szociolingvisztikai szempontjait figyelembe véve viszont meghaladottnak tekinthetjük azt a felhívását, hogy a diákságot mindig figyelmeztetni kell nyelvhasználatbeli vétségeikre, sőt nagy költőink hibáira is! Ma már a nyelvészek nagy része erre a fajta attitűdre úgy tekint, mint az emberi jogok megtiprására, úgy vélik, hogy mindenkinek szabadságában áll az otthon tanult nyelvváltozatát használni, és hogy

1 KRIstóf György: Tudománymúvelés - kollégiumainkban. Református Szemle, 1931, 20. 
esetleg javasolni szabad, tanácsolni a normatívabb megszólalási formákat. Végszóként mondja: ha elszíntelenedik, tartalmát veszti a magyar szó, a magyar kiejtés és hangsúly, ellaposodik az értelmes, világos magyar nyelv is.

Kialakult, szilárd véleménye van tehát a nyelvi tervezést illetően, és ezzel a kor nyelvészeti szokásrendjébe igazodik.

Következő múvével már az irodalom világába kalauzolja el az olvasót, címe $A z$ erdélyi magyar irodalom multja és jövóje (Kolozsvár, Minerva Irodalmi és Nyomdai Műintézet Rt., 1924).

Az előszóban meghatározza az erdélyi irodalomkutatás státusát, és megállapítja, hogy soha nem tekinthető különálló entitásnak, hanem az egyetemes műveltség részének, az e téren való tájékozódás nélkül csak félműveltség van. Ezért szükség van egy egységes magyar közművelődési programra az elcsatolt részeken. Véleménye szerint nincs külön erdélyi magyar műveltség és külön erdélyi irodalom, a magyar múvelődés eszménye nem bomlott meg! Akkoriban tehát még nem alakult ki a transzszilvanizmus szeparációs konnotációja. Régi és elkoptatott metafora: az irodalom - tükör megfeleltetés ${ }^{2}$ : híven mutatja egy nép érzés- és gondolatvilágát, jellemét, és ha össze is törik több darabra, a legkisebb darab is ugyanazon tulajdonságokkal bír, mint az egész. Az erdélyi magyar irodalom is ugyanígy egy darabja az egésznek.

Ugyanezen könyv másik fejezete A Magyar Tudományos Társaságok történetéböl (A magyar tudományos élet fejlettsége a XX. század elején) szemelget. Ennek alapgondolata, hogy az iskola és tudóstársaság fogalmakról értekezik mint tudományos csoportosulásokról: különállás jellemzi őket: az iskola csak közvetítője a tudományoknak. A tudomány előcsarnoka a tudás és az ismereteken nyugvó közműveltség. Az első cél a tudásra nevelés s csak másodsorban a tudománynak önmagáért való fejlesztése. A tudományos társaságokban viszont nem a kész anyag közlése, hanem a meggondolatlan kérdések fejtegetése és megvitatása a fö ${ }^{3}$. A tudós társaságok nyomvonalán az első Erdélyi Muzéumról is cikkez, röviden kitekint történetére, és megállapítja, hogy az első magyar folyóirat, amely a szemle elnevezést méltán kiérdemli, változatos tartalma, tudományos és múvészi színvonala révén. Kritikai véleménye hasonló a Jancsó Eleméréhez. Annak utódját, a második Erdélyi Múzeumot ítéli egyedül arra érdemesnek, hogy egyetemi hallgatók publikálják benne írásaikat. Ezzel a gondolattal indítja a $M a-$ gyar irodalomtörténet a kolozsvári egyetemen című részt. Arról értekezik, hogy a karizmatikusabb egyetemi előadók iskolákat teremtettek meg, ilyen volt a korszakban pl. Ferenczi Zoltán, aki az irodalmat történeti diszciplínaként oktatta. A különböző iskolákat a tudomány másmás szempontú művelése hozza létre. Megemlíti, hogy volt még egy ismert tanára a kolozsvári egyetemnek, Széchy Károly, de valahogy mégsem képviselt egy olyan újszerú álláspontot, eredeti gondolkodásmódot, hogy követői maradtak volna fenn, és egy ún. iskolát alakíthatott volna ki maga körül.

Az utolsó nagy fejezetnek $A$ romániai magyar szellemi élet nebány problemája címet adta. Az uralomváltás a vízválasztó a romániai magyar szellemi élet hullámzó lüktetésében szerinte. 1919 után a tudományművelés, a tudományos élet mozdult meg legutolsóként. Először inkább rövidebb tanulmányokkal és népszerűsítő célú füzetekkel találkozunk. Sok a gátló kö-

2 L. KRIstóf György: Az erdélyi magyar irodalom multja és jövöje. Kolozsvár, Minerva Irodalmi és Nyomdai Múintézet Rt., 1924. 11.

3 Vö.: Kristóf: i. m. 191. 
rülmény: 1. a tanárok számának megcsappanása (a tudományos eredmények előállítását, a tudományos vizsgálódást, ha erdélyi vonatkozású, akkor Erdély földjén lehet hitelesen művelni - mondja Kristóf), 2. a mesterek elnémulása vagy kelletlen szerepcseréje $e^{4}$. Ha nincsenek mesterek, akkor tanítványok sem., 3. egy tudományos intézmény, szervezet hiánya. Az EME volna hivatott ilyenné átalakulni és kifejlődni. Azonban anyagi ereje devalválódott. „S mert tisztes múltjában a múzeális gondolat, az akadémiai eszme s a népszerüsítő irány párhúzamosan, ha nem is mindig egyenlő mértékben, érvényesült: nehéz a jelenben való elhatározása. Fönntartsa-é a régi célt, vállalva a szinte lehetetlent? Gyưjtse, tárolja és közölje a múzeális anyagot? Avagy egész erejével igyekezzék talpra állítani a szakosztályok működését? $\mathrm{S}$ ha ez utóbbit választja, milyen legyen az egyes szakosztályok munkája? Elvont, akadémiai, szakirá-

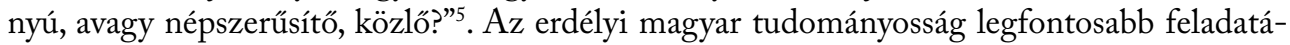
nak tekinti, hogy „földünknek ... s fajunknak ... jelen helyzetét és múltját, erejét és gyöngéit, erényeit és hibáit összegyüjtenűnk, tudományosan feldolgoznunk és megismernünk önmagában is, de a velünk együtt élő népekhez való viszonyában is"6. Hozzáfüzi viszont, hogy az adatgyújtésben nagy hiányosságok mutatkoznak. Véleménye szerint pl. az etnográfiai és népművészeti anyaggyưjtés le nem zárható folyamat. Pozitivista hozzáállás jellemzi szerzőnket a kor tudományos szemléletébe szervesen bekapcsolódva: az adatgyüjtés az elsődleges, hiszen anélkül nem állíthatók fel hipotézisek. Fontos pedig, hogy felismerjük az általánosban a különöst, az egyetemesben az egyénit (deduktív módszerek). Az adatgyüjtés után következik a hivatott szaktudomány kritikai és feldolgozó munkája. A gyüjtéshez magához nem szükséges nagy szaktudás, a gyüjtő legyen „egy érzékeny lemez, amely a tárgyat ugyszólva lemásolja úgy, ahogy van" 7 . Az adat és a róla való vélemény élesen elkülöníthető egymástól, ahol e két elem összevegyítve fordul elő, az tudományos szempontból értéktelen. (ha a gyüjtő nem szaktekintély). A szaktudósok Kristóf reményei szerint az EME keretében fognak csoportosulni. A tudományágakat interdiszciplinárisan szemléli, és szerinte általában véve a honismereti tudományok művelése a legégetőbben sürgős.

Azz utolsó bekezdésekben a tudományos központokról, társaságokról ejt újra szót mint a tudományművelés fellegvárairól Erdélyben: az EME-ről eléggé elmarasztaló a véleménye: kijelenti, hogy csak az egyetemmel szerződéses viszonyban levő gyüjteményeit tekintve fejlődött kellő ütemben, de - és idézem -: ,ama többi hivatását, hogy a gyűjtemények anyagát köztudatba átvigye; hogy közleményeivel s a gyưjtemények tudományos és népszerüsítő ismertetése által a közönséggel eleven kapcsolatot fejlesszen ki; hogy az erdélyi tudósokat és tehetségeket maga köré gyüjtse; s végül, hogy az Erdély földjével és az erdélyi népek sorsával kapcsolatos, sajátosan erdélyi tudományos feladatokat rendszeres egyetemességgel kutassa, előbbrevigye s így az erdélyi problémát felszínen tartsa s a megoldás irányában érlelje: elmulasztotta" $"$.

Az irodalomtörténész utolsó műve, amelyre kitérek előadásomban a Kritikai szempontok az erdélyi irodalmi életben (Kolozsvár, Minerva, 1931) címü. Ebben irodalomelméleti fejtege-

4 Vö.: KRISTóf: i. m. 270.

5 KRISTóf: i. m. 272-273.

6 KRISTóf: i. m. 273-274.

7 KRISTóf: i. m. 277.

8 KRISTóf: $i$. m. 281. 
tésekkel találkozunk, az irodalmiság mibenlétét kutatja szerzőnk. Felteszi a kérdést, hogy mi az irodalom. Mely az irodalmiság azon ismertetője, amely bizonyos tényeket, elemeket kizár az irodalmi tudatból, másokat pedig abba tartozóként jelöl ki? Arra a következtetésre jut, hogy a művészi kifejezés a legspeciálisabb ismertetőjegye az irodalmiságnak. Költői definícióját az irodalomnak egy metaforában találja meg, mégpedig az irodalom mint folyam párhuzamban: forrása az egyes írók és múvek, valamint tartalma is. Medre az olvasóközönség. A meder szabályozója az irodalmi tudat. Egy másik meghatározása szerint az irodalom a szellem kifejezője (a szellemtudományokkal való kacérkodásra utalhat ez az elszólás), az irodalmi művek fokmérője pedig az értékelméleten nyugvó esztétika. Ezután rátér arra, hogy mitől lehet speciálisan erdélyi egy irodalmi mű: 1. erdélyi nyomtató műhelyben készült, 2. a szerző erdélyi, 3. ha a tárgya erdélyi. A legerdélyibb, amely mindhárom feltételt teljesíti! Az író erdélyi, ha: 1. ha származása erdélyi, még akkor is, ha mưveit nem itt írja, 2. ha Erdélyben él és alkot, de sem származása, sem könyve tárgya nem erdélyi. Az erdélyi fogalmát szűkkörűen használja, csak a történelmi Erdélyt érti rajta, ezért javasolja kellő esetben e fogalom helyett a romániai magyar használatát, amely magában foglalja a Partiumot, Bánságot is. Nem mulasztja el megjegyezni azonban, hogy „az erdélyiség csak a művészet síkjára felemelve jelent értéket" ${ }^{9}$ - a Transilvánizmus (1926) c. fejezetben.

Az esztétika nemzetközi problémái című tanulmányában (ugyanebből a kötetből) az előbbi gondolatkörhöz kapcsolódóan megjegyzi, hogy a tudományok addig nemzetköziek, amíg megmaradnak az elmélkedés síkján. A gyakorlatban már nemzeti jelleget öltenek. „A probléma mindig nemzetközi, tárgyalása, megoldása azonban mindig nemzeti dicsőség és nemzeti erény" ${ }^{10}$. Jellegzetesen pozitivista ihletettségű eszmefuttatással zárja tanulmányát a tudományosságot illetően: nem a kongresszusok parádés előadásai és csillogó vitái fejlesztik, hanem a levéltári kutatás vagy az íróasztal melletti csendes kontempláció.

Az utolsó fejezetben, a Tíz év az erdélyi magyarság irodalmi életéból (1929) címúben szintén az erdélyiség értelmezésébe bocsátkozik. Elítéli az erdélyiséget mint puszta modorosságot, megjegyzi, hogy bármely vidékiesség vagy nyelvjárás csak forrása, kiindulópontja lehet a valódi műalkotásnak. „Irodalmunk nem járhatja a vidékiesség zsákutcáját s nem elégedhetik meg még oly divatos manírokkal sem"11. A transzszilván irodalom társadalmi meghatározottságáról szólva, kimondja, hogy szerinte a a nemzettársadalom lelkiállapota iránt közömbös, hideg, érdektelen és érzéktelen esztéticizmus csak játék, ügyeskedés. Az erdélyi regényirodalmat felosztja történetire és társadalmira (ez a kategorizáció kissé mondvacsinált, még a saját elvei alapján is): történeti írók Gulácsy Irén, Gyallay Domokos, P. Jánossy Béla, Kós Károly, Makkai Sándor, Nyirő József és Tabéry Géza. Társadalmi írók: Berde Mária, Szabó Mária, Antal Áron, Donáth László, Karácsony Benő (azt írja, hogy Karácsony messze elmarad Berde Mária mögött múvészi színvonalban, jó tollú újságírónak tartja, de nem múvészi ítélete szerint), Kádár Imre, Ligeti Ernő, Markovits Rodion (Kristóf szerint a Szibériai garnizon irodalmi értéke problematikus), Nagy Dániel, Molter Károly, Morvay Zoltán, Papp József, Szántó György, Székely Jenő. Értékítéleteivel is lehet vitatkozni, mint látható.

9 Uő: Kritikai szempontok az erdélyi irodalmi életben. Kolozsvár, Minerva, 1931. 56.

10 KRISTóf: i. m. 71.

11 KRISTóf: i. m. 93. 
Kristóf tudományszemléletéről összefoglalóan elmondhatjuk, hogy egyfajta holisztikus látásmód jellemzi, a már élesen elkülönülő szaktudományok az ő felfogásában még szervesen összetartoznak, a tudományos munkamódszereket illetôen a kor és fôként Erdély kissé már meghaladott nézeteihez igazodva pozitivista elveket vall (dedukción alapuló kutatások, minuciózus anyaggyüjtés, a feldolgozás és értelmezés terén megmutatkozó hiányosságok stb.), illetve a tudományok szociális beágyazottságának nagy szószólója.

Végül, de nem utolsósorban rátérnék Tavaszy Sándor néhány munkájának kiértékelésére tudományelméleti szempontból. Tavaszy sokrétű tudományos tevékenységének egyik vágánya a tudományfilozófiában való elmélyedés. Kontemplációival e téren megismerkedhetünk $A$ jelenkor szellemi válsága (Kolozsvár, Minerva, 1923) címú írásának olvasásával. Ennek 6. fejezete foglalkozik konkrétan a tudományosság világában felfedezhető válsággal. Véleménye szerint a mai tudományosságot válságba sodorta, hogy elveszítette szintetikus erejét. A tudományos szakkutatás differenciálódása következtében millió mikrokozmoszt fedezett fel, de közben elveszítette szem elől a makrokozmoszt. Felburjánzott a filozófiában is a természettudományos szakszerűség, és létrehozott egy szőrszálhasogató, terméketlen skolasztikát. Tavaszy szerint ez a korlátolt szakszerűség eredményezte az Einstein-féle relativizmust, amely a jelenkor tudományos válságát betetőzte. A racionalizmus-irracionalizmus ellentétpárról is kifejti véleményét: az irracionális intuíció vagy átélés, tapasztalás egy diadalmas szellemi tettel, egyszerre veszi birtokába a jelenséget, a racionális mindig lépésről lépésre hódítja meg a dolgokat. „Az európai keresztyén kultúra ideálja, amelyhez való alkalmazkodástól függ a jövője, az, hogy a rácionalismusra és irrácionálismusra való kettős törekvést, egyensulyban tartsa" ${ }^{12}$ A Befejezésben elmondja, hogy ezek az új jelenségek, mint irracionalizmus, relativizmus, kóros, veszedelmes tünetek, válságra mutatóak. Ennek ellenére reményeit fejezi ki azzal kapcsolatban, hogy a nagy értékek ideiglenes devalválódása után újabb nagyszerű perspektíváknak néz elébe még a nyugat-európai kultúra. Utoljára még megjegyzi, hogy a jelenkorban a tudományosság fokmérője a hasznosság lett, ez is egyfajta devalválódás.

Egy másik művében, a Világnézeti kérdések (Torda, Füssy József Irodalmi és Könyvnyomdai Múintézete. Torda, 1925.) címúben az erdélyi magyar kultúra és tudományos élet kérdéseit Spengler filozófiájának szûrôjén át nézve tárgyalja. A Nyugat alkonyának írója szerint minden korszaknak megvan az uralkodó kultúrája. Ma a nyugat-európai kultúra játssza az uralkodó szerepet. A nyugat-európai kultúrát pedig fausti jellegűnek nyilvánítja. Fausti abban az értelemben, hogy a határtalan felé epekedik, a kialakult értékek iránti bizalmatlanságában, a terméketlen kételkedésében, a nyughatatlanságában. Spengler szerint, amely nép lelkén már átizzottak a kultúrák, az már csak salak, amely nép még csak várja ezt, az még nyersanyag. Ez az erdélyi magyar kultúra státusa Tavaszy értelmezésében, tehát még van esélye az újszerü kutatásoknak és az értékes eredmények felmutatásának szerinte. Tavaszy, ha csak e vázolt formában feltüntetett eszmefuttatásait tekintjük is, láthatólag a szellemtudományok nézeteit vallja magáénak, és Kristóf Györggyel, Erdélyi Múzeum-beli munkatársával ellentétben a pozitivizmus ellenlábasának tekinthető, viszont mégis a tudományok idealistább, nagy Egészként való, organikus felfogása rá is jellemző, úgy ahogy Jancsó Elemér írásában is nagyfokú érzékenységet tapasztalhattunk a rész-egész szemlélet irányában.

12 Tavaszy Sándor: A jelenkor szellemi válsága. Kolozsvár, Minerva, 1923. 25. 


\section{THE SCIENTIFIC APPROACH OFTHE ERDÉLYI MÚZEUM'S AUTHORS IN THE INTERWAR PERIOD}

\section{Keywords: scientific approach, theory of sciences, history of sciences, theory of literature, history of philosophy.}

In this present lecture I thought I would analyse the above-mentioned authors' other writings, not those published in the Transylvanian review Erdélyi Múzeum in the interwar phase. The purpose of my work was to form an idea of these writers' notions, conceptions about science and to understand the direction line of their activity regarding the Erdélyi Múzeum on the basis of their significant works. After I looked through the respectable issues of the Erdélyi Múzeum I chose the following scholars because of their papers' „overtones” regarding the theory of sciences, their absorbed methodology of research and their discussion regarding this domain: Jancsó Elemér literary historian, Kristóf György literary historian and Tavaszy Sándor reformed teacher of divinity and philosopher.

\section{CONCEPT,IA ȘTIINT,IFICĂ A AUTORILOR MUZEULUI ARDELEAN DIN PERIOADA INTERBELICĂ}

\section{Cuvinte-cheie: concepție științifică, teoria științelor, istoria științelor, teoria literaturii, istoria filozofiei.}

În prelegerea actuală mi-am propus să analizez niște alte scrieri ale autorilor menționati mai sus, nu cele apărute în Muzeul Ardelean din perioada interbelică. Scopul lucrării este de a conceptualiza ideile, teoriile lor despre știință și de înțelege linia de conduită a activității lor în Muzeul Ardelean pe baza unor lucrări mai importante ale lor. După ce am parcurs numerele revistei din perioada interbelică am desemnat câţiva oameni de știință care prin formaţia lor iniţială, prin preocupările referitoare la teoria științei, prin metodologia lor aprofundată de cercetare și operele lor privind acest domeniu pot fi de interes știinţific ridicat: istoricul literar Jancsó Elemér, istoricul literar Kristóf György, profesorul în teologia reformată precum și filosoful Tavaszy Sándor. 